\title{
Characterization of the Protease Activity
}

\section{in the Chemotactic Factor Inactivator}

\author{
Peter A. Ward and Jurus Ozols \\ From the Departments of Pathology and Biochemistry, University of Connecticut \\ Health Center, Farmington, Connecticut 06032
}

A B S T R A C T The chemotactic factor inactivator (CFI) isolated from human serum contains a kininase activity that causes extensive hydrolysis of bradykinin. The highly chemotactic synthetic peptide Met-Leu-Phe was completely hydrolyzed by CFI preparations. The release of the constituent amino acids from this peptide coincided with a loss of its chemotactic activity. The $N$ formyl, but not the amide derivative, of the leukotactic peptide Met-Leu-Phe was resistant to the action of CFI, as evidenced by chemotactic and biochemical assays. Examination of the specificity of CFI proteolysis revealed that short polypeptide substrates are degraded sequentially from the amino terminus. Larger peptides are less extensively hydrolyzed, and the patterns of hydrolysis are more complex. Inactivation of the bacterial chemotactic factors by CFI was overcome by the addition of high concentrations of peptides which were substrates for CFI. CFI preparations readily hydrolyzed the peptide Arg-Phe-Ala. The constituent amino acids were conveniently identified by thin-layer chromatography method. This procedure afforded a rapid assay for measuring CFI activity in the whole human serum as well as in fractions throughout the purification steps. Moreover, CFI also hydrolyzed L-leucyl- $\beta$-napthylamide at rates comparable to peptides. Thus, L-leucyl- $\beta$ napthylamide served as a useful substrate for estimating CFI activity in preparations at various stages of purification. This substrate was also useful in kinetic studies. The results from these studies indicate an aminopeptidase activity is the mechanism whereby CFI inhibits the activity of chemotactic substrates.

\section{INTRODUCTION}

The chemotactic factor inactivator $(\mathrm{CFI})^{1}$ present in human serum has the ability to irreversibly inactivate a

Received for publication 13 November 1975 and in revised form 11 February 1976.

${ }^{1}$ Abbreviation used in this paper: CFI, chemotactic factor inactivator. series of peptides that exhibit leukotactic activity (1, 2). Although CFI has been thought to be an enzyme, no direct evidence, thus far, has been obtained to support this hypothesis. In this report we provide direct evidence that CFI isolated from human serum has an inherent aminopeptidase activity.

\section{METHODS}

CFI. CFI was isolated from preparations of fresh human serum by a combination of procedures, including salt fractionation, gel filtration using Sephadex G-150 (Pharmacia Fine Chemicals Inc., Piscataway, N. J.), followed by ionic exchange chromatography in DE-52 cellulose, gel filtration in Sephadex G-200, and preparative electrophoresis in Pevikon or polyacrylamide gels. Details of these procedures are given in a recent publication (2). In several of the experiments to be described, CFI was obtained at the fourth step of fractionation (Sephadex G-200). In other experiments, where specified, further purification involved preparative electrophoresis. Unless atherwise indicated, $50-\mu 1$ vol of CFI (15-65 $\mu \mathrm{g}$ protein) were incubated with $50 \mu \mathrm{l}$ of chemotactic factor and $100 \mu \mathrm{l}$ of sodium phosphate buffer $(\mathrm{pH}$ 7.4, $0.05 \mathrm{M}$ ).

Chemotactic analysis was performed with rabbit neutrophils suspended in $0.1 \%$ bovine serum albumin, using micropore filters with porosity $0.65 \mu \mathrm{m}$ and using modified Boyden chambers (3). Chemotactic counts were determined by the assessment of the total number of migrated cells in five randomly selected microscopic fields, $\times 140$ magnification. Calculation of CFI activity was made after the results of neutrophil migrational responses to $50 \mu \mathrm{l}$ of the bacterial chemotactic factor. The latter was isolated from the supernatant fluid of an Escherichia coli culture (2). The amount of inhibition of chemotactic activity was calculated, relative to the chemotactic counts in an untreated chemotactic factor control $(1,2)$. Protein was determined by the method of Lowry et al. (4) using bovine serum albumin as standard. Synthetic peptides. Peptide substrates were purchased from Research Plus Laboratories, Inc. (Denville, N. J.),

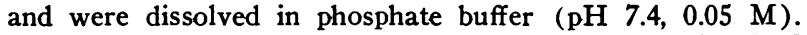
In some cases it was necessary to lower the $\mathrm{pH}$ with $1 \mathrm{~N}$ $\mathrm{HCl}$ to achieve solubility of the peptide, followed by adjustment to neutral $\mathrm{pH}$. Concentrations of the peptides are listed in the entries within the tables. Bradykinin was purchased from Sigma Chemical Co. (St. Louis, Mo.). Chemotactic peptides were gifts from Drs. Richard Freer and 
TABLE I

Bradykininase Activity in CFI Preparations

\begin{tabular}{ccc}
\hline CFI preparation* & Preparation & $\begin{array}{c}\text { Inactivation of } \\
\text { bradykinin } \neq\end{array}$ \\
\hline \multirow{3}{*}{$\alpha$-Globulin } & & $\%$ decrease \\
& a & 86 \\
$\beta$-Globulin & $\mathrm{b}$ & 12 \\
& $\mathrm{c}$ & 38 \\
\end{tabular}

* Electrophoretically purified samples $(30 \mu \mathrm{g})$ of CFI, obtained after a series of fractionation steps (2), were used. ¥ As determined by bioassay, after a 4 -h incubation of CFI with $20 \mu$ g bradykinin.

Elmer Becker (University of Connecticut Health Center, Farmington, Conn.).

Bradykinin assays. Bioassay on the estrus rat uterus was performed in the conventional manner (5). The percent of bradykinin activity lost was calculated after establishing a dose response with a solution of bradykinin at known concentrations. We are indebted to Dr. Richard Freer (Department of Pharmacology, University of Connecticut Health Center) for his assistance.

Amino acid analysis. The amino acid composition of samples was determined using two procedures. The first involved the standard, Moore and Stein method using Beckman Spinco model 120C amino acid analyzer (Beckman Instruments, Inc., Spinco Div., Palo Alto, Calif.) (6). For all experiments, samples were diluted to $1.0 \mathrm{ml}$ with $0.2 \mathrm{M}$ citrate buffer $\mathrm{pH} 2.2$ to stop the enzymatic reaction. Aliquots were then immediately subjected to quantitative analysis or frozen $\left(-60^{\circ} \mathrm{C}\right)$ for later study. The second procedure involved qualitative analysis of amino acids released from peptides after incubation with CFI. This assay was accomplished by thin-layer chromatography using precoated activated silica (Anasil, type $\mathrm{C}$ ) plates, which were obtained from Analabs, Inc. (North Haven, Conn.). One-dimensional chromatography was performed using a solvent consisting of isopropyl alcohol, formic acid, and water $(40: 2: 10)$. The developed plates were sprayed with ninhydrin solution and the amino acids identified by comparing their mobilities with amino acid standards. Identification of the unknown spots was made on the basis of comparson with standards.

The peptidase activity in CFI preparations was readily assayed by determining the extent of hydrolysis of peptide Arg-Phe-Ala using thin-layer chromatography. $20 \mu 1$ of peptide $(0.1 \mathrm{mM})$ was incubated with $10 \mu \mathrm{l}$ of CFI preparation, along with $25 \mu 150 \mathrm{mM}$ phosphate buffer $\mathrm{pH} 7.4$. After incubating at $37^{\circ} \mathrm{C}$ for $1 \mathrm{~h}, 10-\mu \mathrm{l}$ aliquots were spotted on plates for immediate thin-layer chromatography analysis. Peptide bond hydrolysis could be readily detected by the formation of free arginine spots. Spots corresponding to the two other amino acids of this peptide could also be recognized in some CFI digests. The presence of any of the free amino acids was considered a positive evidence for CFI activity.

Leucine aminopeptidase activity. Enzyme activity was assessed spectrophotometrically using the substrate L-leucyl$\beta$-napthylamide. After hydrolysis, the liberated $\beta$-napthylamine was reacted with a diazo compound, and the color of the reaction measured according to the procedure described in Analytical and Diagnostic Bulletin no. 251 of Sigma Chemical Co. The reagents for this assay were obtained from the Sigma Chemical Co.

Determination of the $p H$ optimum of the peptidase activity. To assess the $\mathrm{pH}$ optimum for leucine aminopeptidase activity in the CFI preparations, Tris-maleate buffer (Sigma Chemical Co.) was used at a concentration of 0.05 M. $50 \mu 1$ of buffer was added to a mixture containing 50 $\mu \mathrm{l}$ CFI and $200 \mu \mathrm{l}$ substrate, L-leucyl- $\beta$-napthylamide. After incubation for $1 \mathrm{~h}$ at $37^{\circ} \mathrm{C}$, the assay for free $\beta$-napthylamide was performed using the diazonium reagent.

\section{RESULTS}

Bradykininase activities in CFI preparations. Highly purified CFI preparations, consisting of a single $\beta$ globulin band and only three other $\alpha$-globulin bands, were obtained by elution from preparative polyacrylamide gels after electrophoresis (2). As shown in Table $\mathrm{I}$, incubation of $30 \mu \mathrm{g}$ of CFI preparations with $20 \mu \mathrm{g}$ bradykinin at $\mathrm{pH} 7.4$ for $4 \mathrm{~h}$ at $37^{\circ} \mathrm{C}$ led to a decrease of bradykinin activity ranging from 12 to $85 \%$. This indicates that the most highly purified preparations of CFI, which appeared as a single band on analytical polyacrylamide gel electrophoresis, contained a bradykininase activity.

To determine the nature of the inactivation of bradykinin by CFI preparations, the $\alpha$ - and $\beta$-globulin forms were incubated with $200 \mathrm{nmol}$ of bradykinin for 1

TABLE II

Hydrolysis of Bradykinin by CFI Arg-Pro-Pro-Gly-Phe-Ser-Pro-Phe-Arg

\begin{tabular}{|c|c|c|c|c|c|c|c|}
\hline \multirow{2}{*}{$\begin{array}{c}\text { CFI } \\
\text { preparation* }\end{array}$} & \multirow[b]{2}{*}{ Protein } & \multirow{2}{*}{$\begin{array}{l}\text { Inactivation of } \\
\text { chemotactic } \\
\text { factor }\end{array}$} & \multicolumn{5}{|c|}{$\begin{array}{l}\text { Nanomoles of amino acids released } / 200 \mathrm{nmol} \\
\text { of bradykinin } \ddagger\end{array}$} \\
\hline & & & Arg & Gly & Ser & Phe & Pro \\
\hline & $\mu g$ & $\%$ decrease & & & & & \\
\hline$\beta$-Globulin & 45 & 76 & 197 & 89 & 18 & 316 & 27 \\
\hline$\alpha$-Globulin & 62 & 73 & 196 & 60 & 15 & 352 & 213 \\
\hline
\end{tabular}

* Samples were inactivated with $0.2 \mathrm{M}$ sodium citrate buffer and analyzed on a Beckman Spinco model $120 \mathrm{C}$ amino acid analyzer.

$\ddagger$ The composition of bradykinin was: $\mathrm{Arg}^{2}, \mathrm{Ser}^{1}, \mathrm{Pro}^{3}, \mathrm{Gly}^{1}, \mathrm{Phe}^{2}$. 
TABLE III

Hydrolysis of Various Chemotactic Peptides by CFI

\begin{tabular}{lccccc}
\hline \multicolumn{1}{c}{ Chemotactic peptide* } & $\begin{array}{c}\text { CFI } \\
\text { preparation }\end{array}$ & $\begin{array}{c}\text { Inactivation of } \\
\text { chemotactic } \\
\text { activity }\end{array}$ & & \multicolumn{2}{c}{$\begin{array}{c}\text { Residues of amino acids released/ } \\
\text { nmol of peptideł }\end{array}$} \\
\cline { 5 - 7 } & Mg protein & $\%$ & Met & Leu & Phe \\
Met-Leu-Phe & 65 & 74 & 1.03 & 0.83 & 0.85 \\
Met-Leu-Phe & - & Acid hydrolysis & 1.00 & 1.00 & 0.97 \\
$N$-formyl-Met-Leu-Phe & 65 & 14 & 0.0 & 0.06 & 0.12 \\
$N$-formyl-Met-Leu-Phe & - & Acid hydrolysis & 0.88 & 1.03 & 1.06 \\
\hline
\end{tabular}

* Synthetic peptides (approximately $100 \mathrm{nmol}$ ) were incubated with CFI preparations for

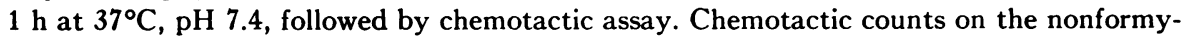
lated and formylated tripeptides were 280 and 310 , respectively, with a negative control of 20 for background.

$\ddagger$ The amino acid composition of the CFI digest or the acid hydrolysate of the peptide was determined with an amino acid analyzer; $100 \mathrm{nmol}$ of peptide was used in each experiment.

$\mathrm{h}$ at $37^{\circ} \mathrm{C}, \mathrm{pH} 7.4$, in a volume of $200 \mu \mathrm{l}$. The reaction mixtures were then immediately diluted to $1.0 \mathrm{ml}$ with $0.2 \mathrm{M}$ citrate buffer ( $\mathrm{pH} 2.2$ ), and the samples were examined directly on an amino acid analyzer. The results are shown in Table II. Each CFI preparation was highly active, causing a $73-76 \%$ reduction of the bacterial chemotactic factor activity. The same CFI preparations, when mixed with bradykinin, caused extensive hydrolysis of the peptide. Free arginine, glycine, serine, phenylalanine and proline were found in the digest. These findings indicate that CFI preparations cause extensive hydrolysis of bradykinin.

CFI hydrolysis of synthetic chemotactic peptides. It has recently been shown that specific synthetic peptides have leukotactic activity (7). Several of these peptides were tested as possible substrates of CFI. The CFI preparation examined was isolated by preparative electrophoresis and incubated with chemotactic peptides, such as Met-Leu-Phe and $N$-formyl-Met-Leu-Phe. The digests were then immediately analyzed quantitatively for the presence of free amino acids. The results are shown in Table III. Incubation of CFI with Met-LeuPhe induced a $74 \%$ loss of its leukotactic activity and the release of its component amino acids. Using the results of acid hydrolysis for comparison, virtually complete hydrolysis of the peptide occurred. Similar experiments using the formylated peptide gave very little evidence of inactivation (14\% by chemotactic assay), and yielded less than $10 \mathrm{nmol}$ of any of the component amino acids (Table III). The composition of the formylate peptide, as determined by analysis of acid hydrolysis, is also included in Table III. The inability to detect $\mathrm{N}$ -

TABLE IV

Hydrolysis of Synthetic Hexapeptide by CFI Preparations Leu-Trp-Met-Arg-Phe-Ala

\begin{tabular}{|c|c|c|c|c|c|c|c|c|c|c|}
\hline \multirow{2}{*}{$\begin{array}{c}\text { CFI } \\
\text { prep- } \\
\text { aration* }\end{array}$} & \multirow[b]{2}{*}{ Protein } & \multirow{2}{*}{$\begin{array}{l}\text { Inactivation of } \\
\text { chemotactic } \\
\text { factor }\end{array}$} & \multirow{2}{*}{$\begin{array}{l}\text { Incubation } \\
\text { time }\end{array}$} & \multirow{2}{*}{$\begin{array}{l}\text { Peptide } \\
\text { split }\end{array}$} & \multicolumn{6}{|c|}{ Residues released/mole of Leu§ } \\
\hline & & & & & Leu & $\operatorname{Trp}$ & Met & Arg & Phe & Ala \\
\hline & $\mu g$ & $\%$ & $h$ & $\%$ & & & & & & \\
\hline $\mathrm{a}(\beta)$ & 15 & 65 & 18 & 56 & 1.0 & 0.96 & 0.83 & 0.86 & 0.41 & 0.39 \\
\hline a $(\alpha)$ & 48 & 61 & 18 & 28 & 1.0 & 0.71 & 0.46 & 0.14 & 0.30 & 0.32 \\
\hline $\mathrm{b}(\beta)$ & 6 & 40 & 18 & 30 & 1.0 & 1.3 & 0.97 & 1.03 & 0.2 & 0.2 \\
\hline $\mathrm{b}(\alpha)$ & 12 & 55 & 18 & 29 & 1.0 & 1.0 & 0.66 & 0.58 & 0.62 & 0.65 \\
\hline c $(\beta)$ & 12 & - & 1 & 15 & 1.0 & 0 & 0 & 0 & 0 & $\mathbf{0}$ \\
\hline c $(\beta)$ & 12 & - & 2 & 19 & 1.0 & 0.32 & 0 & 0 & 0 & 0 \\
\hline c $(\beta)$ & 12 & - & 4 & 25 & 1.0 & 0.96 & 0.96 & 0.87 & 0.40 & 0.44 \\
\hline c $(\beta)$ & 12 & 72 & 18 & 26 & 1.0 & 0.73 & 1.0 & 1.0 & 0.80 & 0.62 \\
\hline$d(\alpha)$ & 9 & 84 & 2 & 12 & 1.0 & 0 & 0 & 0 & 0 & 0 \\
\hline
\end{tabular}

* Highly purified preparations obtained in preparative electrophoresis after a series of fractionation procedures. $\alpha$ and $\beta$ refer to the type of electrophoretic mobility of the preparation.

$\ddagger$ Percent loss of chemotactic activity in bacterial factor after incubation for $30 \mathrm{~min}$ with CFI.

$\S$ Each CFI incubation mixture contained $100 \mathrm{nmol}$ of the peptide. 
TABLE V

Hydrolysis of Di-and Tripeptides by CFI*

\begin{tabular}{lcl}
\hline \multicolumn{1}{c}{ Peptide substrate } & $\begin{array}{c}\text { Nanomoles } \\
\text { incubated }\end{array}$ & \multicolumn{1}{c}{$\begin{array}{c}\text { Nanomoles of amino } \\
\text { released }\end{array}$} \\
\hline Arg-Phe-Ala & 120 & Arg, 57; Phe, 64; Ala, 63 \\
Pro-Leu-Gly-NH $\mathrm{NH}_{2}$ & 150 & Pro, 29; Leu, 29; Gly, 6.7 \\
$\begin{array}{l}\mathrm{N} \text {-formyl-Met-Phe } \\
\text { Met-Phe-NH }\end{array}$ & 100 & Met, 0; Phe, 0 \\
& 100 & Met, 32; Phe, 15 \\
\hline
\end{tabular}

* $15 \mu \mathrm{g}$ of $\mathrm{CFI}$ was incubated with peptide for $1 \mathrm{~h}$ at $37^{\circ} \mathrm{C}$, $\mathrm{pH} 7.4$, followed by analysis for free amino acids.

formyl-methionine is probably due to its poor reactivity with ninhydrin. These results indicate that Met-LeuPhe, but not its formylated derivative, can be hydrolyzed by CFI.

Hydrolysis of the Hexapeptide by CFI preparations. Highly purified samples (isolated by procedures extending through the preparative electrophoretic step) of CFI were incubated with $100 \mathrm{nmol}$ of the hexapeptide Leu-Trp-Met-Arg-Phe-Ala at different intervals of time (Table IV). The mixtures were then analyzed for the presence of free amino acids. Both the $\alpha$ - and the $\beta$ globulin forms of CFI induced extensive hydrolysis of the peptide. The amino acids present in lowest concentration were phenylalanine and alanine, and these were positioned at the $\mathrm{COOH}$-terminus end of the pep- tide. When short-time $(1 \mathrm{~h})$ incubation of CFI with the hexapeptide was carried out, only the $\mathrm{N}$-terminal amino acid, leucine, was identified. After $2 \mathrm{~h}$ a small amount of tryptophan could also be detected. After prolonged incubation all of the constituent amino acids were present in the digest. These results strongly suggest that the action of CFI entails sequential hydrolysis of the peptide from the amino terminus.

Hydrolysis of di-and tripeptides by CFI. Employing the " $c$ " preparation described in Table IV, CFI was incubated for $1 \mathrm{~h}$ with four different peptides, listed in Table V. Each mixture was then analyzed for the presence of free amino acids after incubation with CFI. Half of all the component amino acids in the Arg-PheAla preparation were released after incubation with CFI. The amidated peptide Pro-Leu-Gly- $\mathrm{NH}_{2}$ also showed evidence of hydrolysis by CFI, although less extensively than Arg-Phe-Ala substrates. The dipeptide $N$-formyl-Met-Phe was resistant to hydrolysis, while Met-Phe- $\mathrm{NH}_{2}$ was readily hydrolyzed by CFI. These findings support those presented in Tables III and IV and are consistent with the action of an aminopeptidase.

Analysis of peptide hydrolysis by thin-layer chromatography. To ascertain if differences could be demonstrated between the peptidase activities of the $\alpha$ - and the $\beta$-globulin forms of CFI, series of di- through octapeptides were incubated with CFI preparations for 2 or

TABLE VI

Thin-Layer Chromatography of CFI-Treated Peptides

\begin{tabular}{|c|c|c|c|c|c|}
\hline \multirow[b]{3}{*}{ Size } & \multirow[b]{3}{*}{ Peptide } & \multicolumn{4}{|c|}{ Free amino acids detected } \\
\hline & & \multicolumn{2}{|c|}{$\beta$-Globulin CFI } & \multicolumn{2}{|c|}{$\alpha$-Globulin CFI } \\
\hline & & $2 \mathrm{~h}$ & $18 \mathrm{~h}$ & $2 \mathrm{~h}$ & $18 \mathrm{~h}$ \\
\hline Di- & $\begin{array}{l}\text { Leu-Trp } \\
\text { Arg-Phe } \\
\text { Phe-Ala }\end{array}$ & $\begin{array}{l}\text { Yes } \\
\text { Yes } \\
\text { Yes }\end{array}$ & $\begin{array}{c}\text { Yes } \\
\text { Yes } \\
*\end{array}$ & $\begin{array}{l}\text { None } \\
\text { Yes } \\
\text { Yes }\end{array}$ & $\begin{array}{c}\text { Yes } \\
* \\
*\end{array}$ \\
\hline Tri- & $\begin{array}{l}\text { Met-Arg-Phe } \\
\text { Leu-Trp-Met } \\
\text { Arg-Phe-Ala }\end{array}$ & $\begin{array}{l}\text { Yes } \\
\text { Yes } \\
\text { Yes }\end{array}$ & $\begin{array}{c}* \\
\text { Yes } \\
\text { Yes }\end{array}$ & $\begin{array}{l}\text { Yes } \\
\text { Yes } \\
\text { Yes }\end{array}$ & $\begin{array}{c}\text { Yes } \\
\text { Yes } \\
*\end{array}$ \\
\hline Quadra- & $\begin{array}{l}\text { Leu-Trp-Met-Arg } \\
\text { Met-Arg-Phe-Ala }\end{array}$ & $\begin{array}{l}\text { Yes } \\
\text { Yes }\end{array}$ & * & $\begin{array}{l}\text { Yes } \\
\text { Yes }\end{array}$ & $*$ \\
\hline Penta- & $\begin{array}{l}\text { Phe-Asp-Ala-Ser-Val } \\
\text { Leu-Trp-Met-Arg-Phe }\end{array}$ & $\begin{array}{l}\text { Yes } \\
\text { Yes }\end{array}$ & $\begin{array}{l}\text { Yes } \\
\text { Yes }\end{array}$ & $\begin{array}{l}\text { None } \\
\text { None }\end{array}$ & $\begin{array}{l}\text { Yes } \\
\text { Yes }\end{array}$ \\
\hline Hexa- & Leu-Trp-Met-Arg-Phe-Ala & Yes & Yes & Yes & Yes \\
\hline Octa- & $\begin{array}{l}\text { Asp-Tyr-Thr-Gly-Trp-Met-Asp-Phe } \\
\text { Phe-Val-Gly-Trp-Leu-Met-Asn-Thr }\end{array}$ & $\begin{array}{l}\text { None } \\
\text { None }\end{array}$ & $\begin{array}{l}\text { None } \\
\text { None }\end{array}$ & $\begin{array}{l}\text { None } \\
\text { None }\end{array}$ & $\begin{array}{l}\text { None } \\
\text { None }\end{array}$ \\
\hline
\end{tabular}

Approximately $20 \mu \mathrm{g} \mathrm{CFI}$ protein was incubated with $200 \mathrm{nmol}$ of peptides $\left(37^{\circ} \mathrm{C}, \mathrm{pH} 7.4\right)$. The mixtures were then analyzed in thin-layer chromatography for evidence of free amino acids. Yes, indicates the presence of free amino acids in larger than trace amounts.

* Not examined. 
$18 \mathrm{~h}$ at $37^{\circ} \mathrm{C}(\mathrm{pH} \mathrm{7.4)}$. Aliquots of the digest were spotted on thin-layer chromatographic plates and subjected to one-dimensional chromatography. The results listed in Table VI indicate that the two forms of CFI ( $\alpha$ - and $\beta$-globulins) both have the ability to hydrolyze a large number of peptides. In a few cases spots were present that could not be identified. The rate of hydrolysis was found to be time-dependent, as demonstrated by a comparison of results obtained at 2 and at $18 \mathrm{~h}$. The two octapeptides appeared to be resistant to hydrolysis. The hydrolysis pattern indicates a preferential release of amino acids from the $\mathrm{N}$-terminal in mixtures incubated for the shorter interval of time $(2 \mathrm{~h})$. This is consistent with the evidence (presented above) which suggests that CFI preparations can hydrolyze a series of peptides and that larger peptides are less susceptible to hydrolysis. The limitations of thin-layer chromatographic analysis make it difficult to assess precisely the nature of hydrolysis of the susceptible peptides.

Inhibition of CFI activity by peptides. The evidence in Table III indicated that with synthetic peptides of known structure, the mechanism of CFI action was related to an aminopeptidase activity. To assess if peptides (which lack chemotactic activity but are susceptible to hydrolysis by CFI) would protect the bacterial chemotactic factor from inactivation by CFI, the experiment outlined in Table VII was performed. Four different peptides, each known to be substrates of CFI but none having chemotactic activity (Table VI), were added at high concentration $(1 \mathrm{mM})$ to a solution containing the bacterial factor followed by the addition of CFI. After incubation at $37^{\circ} \mathrm{C}$ for $30 \mathrm{~min}$, the samples were diluted to $1.0 \mathrm{ml}$ with Hank's medium, and the amount of residual chemotactic activity determined. Appropriate controls were done in which the bacterial factor and peptides were incubated together in

TABLE VII

Protection of Bacterial Chemotactic Factor from Inactivation by $C F I^{*}$

\begin{tabular}{lcc}
\hline $\begin{array}{c}\text { Chemotactic factor in } \\
\text { presence of : }\end{array}$ & $\begin{array}{c}\text { Chemotactic } \\
\text { activity }\end{array}$ & $\begin{array}{c}\text { Loss of } \\
\text { chemotactic } \\
\text { activity }\end{array}$ \\
\hline & counts & $\%$ \\
Buffer & 175 & - \\
CFI* & 20 & 86 \\
CFI + Pro-Leu-Gly-NH2 & 70 & 60 \\
CFI + bradykinin & 155 & 11 \\
CFI + Arg-Phe-Ala & 155 & 11 \\
CFI + Leu-Trp-Met-Arg-Phe-Ala & 200 & 0
\end{tabular}

* Chemotactic factor consisted of $50 \mu$ l culture filtrate from $E$. coli, incubated for $20 \mathrm{~min}$ at $37^{\circ} \mathrm{C}$ with $50 \mu \mathrm{l} \mathrm{CFI} \mathrm{(18 \mu g} \mathrm{protein).} \mathrm{Reaction} \mathrm{volume}$ was $150 \mu \mathrm{l}, \mathrm{pH}$ 7.4. When peptides were present, their concentrations were $1 \mathrm{mM}$ in the case of bradykinin and $0.1 \mathrm{mM}$ for other peptides. After incu. bation, mixtures were diluted to $1.0 \mathrm{ml}$ with Hank's medium and assessed for residual chemotactic activity.

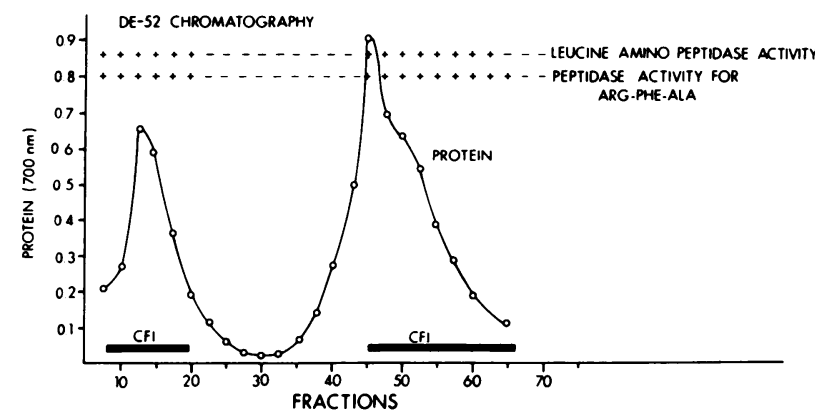

FIGURE 1 Localization of CFI, leucine aminopeptidase, and hydrolase activity for Arg-Phe-Ala in fractions from ionexchange (DE-52 cellulose) chromatography, the second chromatographic step in fractionation procedures for isolation of CFI from human serum.

the absence of CFI, and then analyzed for chemotactic activity. This was necessary to rule out a nonspecific suppressive effect of the peptides in chemotaxis. Under these conditions, no nonspecific suppressive effects were found. The data in Table VII indicate that each of the four peptides tested was able to block the CFI-induced inhibition of the chemotactic factor. The $86 \%$ loss of chemotactic activity caused by CFI dropped from 60 to 11 to $0 \%$ upon addition of various peptide substrates. These data suggest that the CFI-induced inhibition of the bacterial chemotactic factor is due to the proteolytic property of CFI.

Association of CFI, leucine aminopeptidase, and ArgPhe-Ala protease activities during the purification steps of CFI. CFI was isolated by the multi-step procedures recently described (2). In each of these steps CFI, leucine aminopeptidase, and hydrolase activity for the peptide Arg-Phe-Ala were examined. As described earlier, CFI activity was measured by the loss of chemotactic activity in this bacterial factor. In addition, leucine aminopeptidase was measured quantitatively by hydrolysis of Leu- $\beta-\mathrm{NA}$, and hydrolysis of Arg-PheAla using thin-layer chromatography was also employed. The coincidence of each of these three activities during purification of CFI is shown in Figs. 1-3. These steps include ion-exchange chromatography (Fig. 1), gel filtration in Sephadex G-200 (Fig. 2), and preparative electrophoresis (Fig. 3). (The initial purification step involving gel filtration on Sephadex G-150 is not shown, but all three activities also coincided in the same fractions during this gel filtration.) The findings suggest that all three activities reflect the action of the same enzyme.

Effect of $p H$ on the leucine aminopeptidase activity. The $\mathrm{pH}$ optimum of a preparation of CFI, which contained both the $\alpha$ - and the $\beta$-globulin forms of the inactivator, was examined for leucine aminopeptidase activity over a $\mathrm{pH}$ range from 5.0 to 9.0 buffer. Using a 


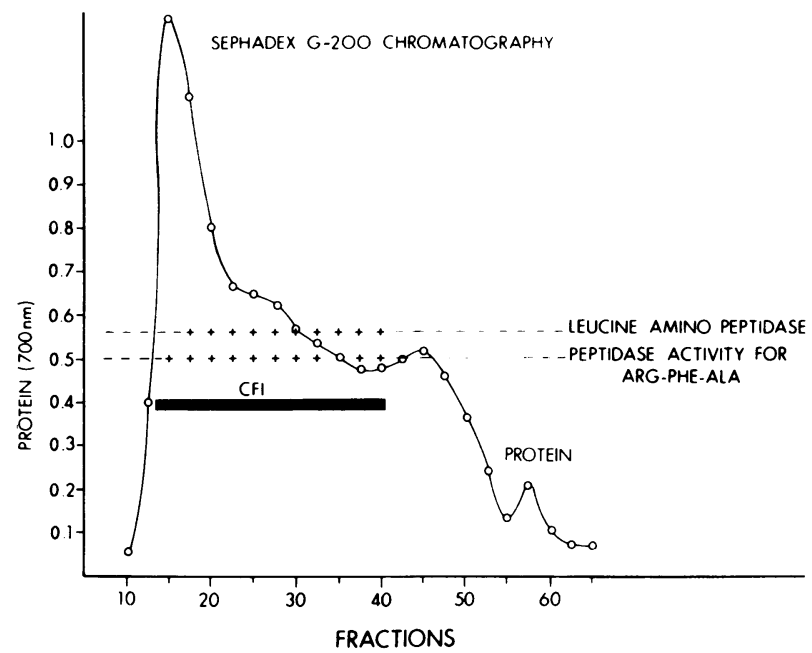

FIgUre 2 Localization of CFI, leucine aminopeptidase, and peptidase activity (for Arg-Phe-Ala) in fractions from gel filtration (Sephadex G-200), the third chromatographic step in the isolation of CFI from human serum.

Tris-maleate buffer the results of this experiment are shown in Fig. 4. Enzymatic activity was found at neutral $\mathrm{pH}$, with maximal enzyme activity occurring between $\mathrm{pH} 6.4$ and 7.6. This is in contrast with the $\mathrm{pH}$ optimum of leucine aminopeptidase isolated from animal tissue extracts, which exhibits its $\mathrm{pH}$ optimum at considerably higher values (7).

\section{DISCUSSION}

These studies suggest that preparations of CFI contain an aminopeptidase activity which accounts for the ability of CFI to irreversibly inactivate leukotactic factors. The most direct evidence for this conclusion comes from the

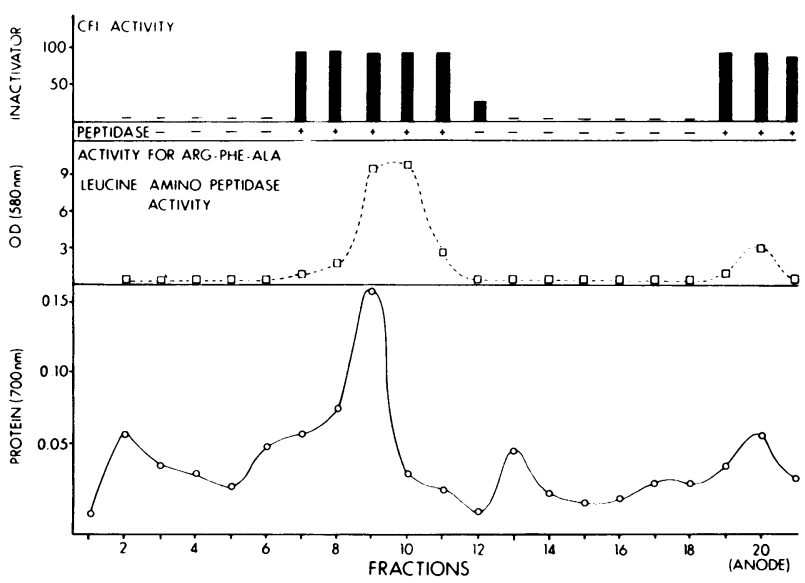

FIGURE 3 Localization of CFI, leucine aminopeptidase, and peptidase activity (for Arg-Phe-Ala), in preparative electrophoresis, the final step in the fractionation of human CFI. All three activities coincide in the chromatogram.

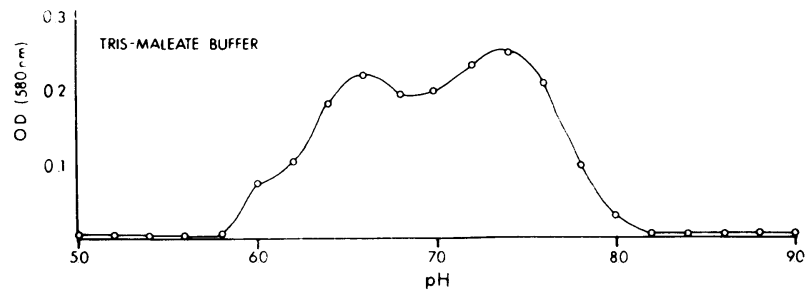

Figure 4 Optimal $\mathrm{pH}$ for leucine aminopeptidase activity, using a CFI preparation from the third chromatographic step, involving Sephadex G-200. A Tris-maleate buffer system was employed. Optical density was read at $580 \mathrm{~nm}$.

hydrolysis studies of synthetic peptides that are highly active as chemotactic factors. The direct demonstration of hydrolysis by CFI of the chemotactically active peptide, Met-Leu-Phe, coincident with the disappearance of chemotactic activity, established the mechanism of inactivation. The resistance of the formylated derivative of the same pepticle to enzymatic hydrolysis as well as to chemotactic inactivation by CFI, along with the studies of CFI-induced hydrolysis of other peptides, established reasonably well the aminopeptidase nature of CFI. In experiments simulating competitive substrate inhibition (Table VII), we have obtained indirect evidence that a similar enzymatic reaction accounts for the CFIinduced inactivation of the bacterial chemotactic factor. Although the structure of the bacterial factor is not definitely known, there is good evidence that it is a peptide (8). The results of peptide-induced protection of the bacterial chemotactic factor from inactivation by CFI are consistent with the thesis that the bacterial chemotactic factor is a peptide and is hydrolyzed by CFI. Although no definitive statements can be made regarding the mechanism by which CFI inhibits the other peptide-related leukotactic factors, such as the C3 and the $\mathrm{C} 5$ fragments from the complement system, it seems likely that these proteins also undergo inactivation by an aminopeptidase action of CFI. Although the $\alpha$ - and the $\beta$-globulin forms of CFI seem to have a "substrate" preference for the $\mathrm{C} 5$ and $\mathrm{C} 3$ fragments (2), respectively, the data from the use of synthetic peptides in this paper do not provide definitive evidence for the substrate specificity of the CFI preparations. The ultimate analysis will have to be done with purified fragments of $\mathrm{C} 3$ and $\mathrm{C} 5$. Obviously, the substrate specificity of the two forms ( $\alpha$ and $\beta$ ) of CFI is not absolute inasmuch as each inactivates the bacterial chemotactic factor (Figs. 3, 4), bradykinin (Table I), and each inactivates a series of synthetic peptides (Table VI).

To what extent the aminopeptidase activity in CFI is related to the well-known leucine aminopeptidase enzyme could not be deduced. Leucine aminopeptidase has been most extensively studied after isolation from hog 
kidney (9). Much less work has been done with a similar, perhaps identical, enzyme present in human serum (10). Leucine aminopeptidase isolated from renal tissue has considerably higher $\mathrm{pH}$ optimum (9) when compared with the enzyme described in this report (Fig. 5). In view of our fractionation data indicating that at every step of the fractionation procedures the aminopeptidase and CFI activities coincide (Figs. 1-3), it seems likely that the aminopeptidase in human serum is identical with CFI, although the experiments do not establish if the aminopeptidase exhibits preferential reactivity with an amino-terminal leucine.

Although CFI preparations clearly showed hydrolytic activity towards the amino-terminal residue of the various synthetic peptides examined, the hydrolysis pattern of bradykinin appeared not to be strictly sequential from the amino terminus. The stoichiometry shown in Table II, however, could be due to the presence of three prolyl residues in the bradykinin molecule. Waley and co-workers (11) report that incomplete hydrolysis of a peptide by aminopeptidases may occur if proline residue is present. They noted that hydrolysis of peptide Ala-Tyr-Glu-Pro-Val-Trp by swine kidney aminopeptidase $M$ gave amino acids Ala, Tyr, Val, and Trp and a diketopiperazine of Glu-Pro (11). The latter peptide derivative was not further hydrolyzed. Thus, CFI digestion of peptides containing proline may yield a complex pattern of hydrolysis.

The elevated levels of leucine aminopeptidase described in the serums of humans with malignant neoplasms is of considerable interest since we have recently demonstrated that serums from patients with Hodgkin's disease have elevated levels of CFI (12). Recently, we have also found that rats bearing malignant tumors in the peritoneal cavity have high levels of CFI in the accompanying ascitic fluid (13). If leucine aminopeptidase activity and CFI are identical (the evidence for which is compelling), it seems reasonable to postulate that the previously recognized presence of leucine aminopeptidase activity in tumor-bearing states may be associated with defects in the ability to express inflammatory responses that involve leukotactic mechanisms (13).

Finally, it should be noted that the aminopeptidase basis for CFI activity is enzymatically very different from that of the anaphylatoxin inactivator which destroys the anaphylatoxin activities of the $\mathrm{C} 3$ and $\mathrm{C5}$ fragments by a single cleavage of their $\mathrm{COOH}$-terminal arginine (14). This carboxypeptidase activity (anaphylatoxin inactivator) appears to be the natural regulator of the anaphylatoxins. If the $\mathrm{C} 3$ and $\mathrm{C5}$ anaphylatoxin derivatives actually contain leukotactic activities (for which there is some evidence), then in- activation of their biological activities could occur by the action either of the carboxypeptidase (anaphylatoxin inactivator) or of the aminopeptidase (CFI). Which of these inactivators is biologically more important has yet to be determined.

\section{ACKNOWLEDGMENTS}

This paper was supported in part by National Institute of Health grants AI 11526, AI 09651, and GM 20520-03 (to J. Ozols).

\section{REFERENCES}

1. Berenberg, J. L., and P. A. Ward. 1973. Chemotactic factor inactivator in normal human serum. J. Clin. Invest. 52 : 1200-1206.

2. Till, G., and P. A. Ward. 1975. Two distinct chemotactic factor inactivators in human serum. J. Immunol. 114 : 843-847.

3. Ward, P. A., C. G. Cochrane, and H. J. Müller-Eberhard. 1965. The role of serum complement in chemotaxis of leukocytes in vitro. J. Exp. Med. 122: 327-346.

4. Lowry, O. H., N. J. Rosebrough, A. L. Farr, and R. J. Randall. 1951. Protein measurement with the Folin phenol reagent. J. Biol. Chem. 193: 265-275.

5. Greenbaum, L. M., R. Freer, J. Chang, G. Semente, and K. Yamafuji. 1969. PMN-kinin and kinin metabolizing enzymes in normal and malignant leukocytes. Br. J. Pharmacol. 36: 623-634.

6. Ozols, J. 1974. Cytochrome $b_{5}$ from microsomal membranes of equine, bovine, and porcine livers. Isolation and properties of preparations containing the membranous segment. Biochemistry. 13: 426-434.

7. Schiffmann, E., B. Corcoran, and S. M. Wahl. 1975. NFormylmethionyl peptides as chemottractants for leukocytes. Proc. Natl. Acad. Sci. U. S. A. 72: 1059-1062.

8. Schiffmann, E., H. V. Showell, B. A. Corcoran, P. A. Ward, E. Smith, and E. L. Becker. 1975. The isolation and partial characterization of neutrophil chemotactic factors from Escherichia coli. J. Immunol. 114: 18311837.

9. Joseph, R. L., and W. J. Sanders. 1966. Leucine aminopeptide extracts of swine muscle. Biochem. J. 100: 827832.

10. Goldbarg, J. A., and A. M. Rutenberg. 1958. The colorimetric determination of leucine aminopeptidase in urine and serum of normal subjects and patients with cancer and other diseases. Cancer. 11: 283-291.

11. Waley, S. G., J. C. Miller, I. A. Rose, and E. L. O'Connell. 1970. Identification of site in triose phosphate isomerase labelled by glycidol phosphate. Nature (Lond.). $227: 181$.

12. Ward, P. A., and J. L. Berenberg. 1974. Defective regulation of inflammatory mediators in Hodgkin's disease. Supernormal levels of chemotactic-factor inactivator. $N$. Engl. J. Med. 290: 76-80.

13. Bronza, J. P., and P. A. Ward. 1975. Antileukotactic properties of tumor cells. J. Clin. Invest. 56: 616-623.

14. Bokisch, V. A., and H. J. Müller-Eberhard. 1970. Anaphylatoxin inactivator of human plasma: Its isolation and characterization as a carboxypeptidase. J. Clin. Invest. 49 : 2427-2436. 